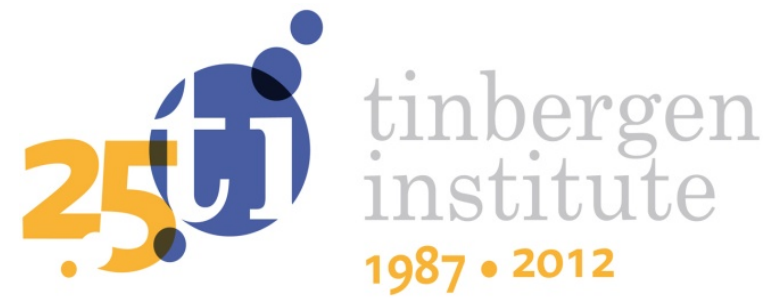

\title{
The Transmission of Monetary Policy through Conventional and Islamic Banks
}

Saijad Zaheer

Steven Ongena ${ }^{3}$

Sweder van Wijnbergen ${ }^{1,2}$

1 Faculty of Economics and Business, University of Amsterdam;

2 Tinbergen Institute;

3 Tilburg University. 
Tinbergen Institute is the graduate school and research institute in economics of Erasmus University Rotterdam, the University of Amsterdam and VU University Amsterdam.

More TI discussion papers can be downloaded at http://www.tinbergen.nl

Tinbergen Institute has two locations:

Tinbergen Institute Amsterdam

Gustav Mahlerplein 117

1082 MS Amsterdam

The Netherlands

Tel.: +31(0)205251600

Tinbergen Institute Rotterdam

Burg. Oudlaan 50

3062 PA Rotterdam

The Netherlands

Tel.: +31(0)10 4088900

Fax: $+31(0) 104089031$

Duisenberg school of finance is a collaboration of the Dutch financial sector and universities, with the ambition to support innovative research and offer top quality academic education in core areas of finance.

DSF research papers can be downloaded at: http://www.dsf.nl/

Duisenberg school of finance

Gustav Mahlerplein 117

1082 MS Amsterdam

The Netherlands

Tel.: +31(0)20 5258579 


\title{
The Transmission of Monetary Policy Through Conventional and Islamic Banks
}

\author{
This draft: April 2012 \\ Sajjad Zaheer* \\ University of Amsterdam \\ E-mail: s.zaheer@uva.nl \\ Steven Ongena \\ CentER - Tilburg University and CEPR \\ E-mail: steven.ongena@uvt.nl \\ Sweder J.G. van Wijnbergen \\ University of Amsterdam and Tinbergen Institute \\ E-mail: s.j.g.vanwijnbergen@uva.nl
}

\begin{abstract}
We investigate the differences in banks' responses to monetary policy shocks across bank size, liquidity, and type, i.e., conventional versus Islamic, in Pakistan between 2002:II to 2010:I. We find that following a monetary contraction, small banks with liquid balance sheets cut their lending less than other small banks. In contrast large banks maintain their lending irrespective of their liquidity positions. Islamic banks, though similar in size to small banks, respond to monetary policy shocks as large banks. Hence ceteris paribus the credit channel of monetary policy may weaken when Islamic banking grows in relative importance. ( 95 words)
\end{abstract}

Keywords: Monetary policy, Islamic Banking, Pakistan.

JEL Classification: E5, G2.

* Corresponding author. We are grateful to the participants of the Eighth International Conference on Islamic Economics and Finance (Doha) for useful comments. We thank the State Bank of Pakistan for providing the data. The views expressed here are those of the authors and do not necessarily represent or reflect the views of State Bank of Pakistan or its subsidiaries. 


\section{Introduction}

Islamic banking is one of the fastest growing segments of the global financial sector. It is currently and expanding at a rate of approximately $20 \%$ per year. In some countries the share of the Islamic financial sector has now reached a size and a level of development such that the financial arrangements it offers are a full-fledged alternative to those in the conventional financial sector. The countries where this has happened includes Malaysia, Iran and the Gulf Cooperation Countries, i.e., Bahrain, Kuwait, Oman, Qatar, Saudi Arabia and United Arab Emirates. Some Asian countries like Bangladesh, Pakistan and Indonesia are also experiencing a phenomenal increase in Islamic finance. Moreover, a number of western countries are now facilitating Islamic banking. And to tap this growing market, large conventional banks that have fairly recently opened an Islamic window includes Barclays, BNP Paribus, Citi Group, Deutsche Bank, Standard Chartered and the Royal Bank of Scotland.

The total volume of Islamic finance was estimated to roughly equal \$1 trillion in 2010 (Standard \& Poor's 2010). Commercial banking comprised the largest share, i.e., 74 percent (International Financial Services London 2010). Investment banking accounted for 10 percent. The remaining part consists of Sukuk (Islamic bonds) and Takaful (Islamic Insurance). Assets of the largest 500 Islamic banks increased by 29 percent to $\$ 822$ billion in 2009 , around the same time when the rest of the world's financial system contracted, and many of the financial institutions were deleveraging their positions. The reason for this starkly different development resides in the fact that Islamic banking tenets do not allow the banks to charge interest and to be involved in the sales of debt instruments. Therefore, Islamic banks did not invest in the kind of instruments that were badly affected during the financial crises, namely derivatives, 
conventional securities and toxic assets. Banning short selling of shares after the crisis is a further reflection of Islamic finance as it stops dealers selling the assets which they do not own. A key question this brisk growth poses to academics and policymakers alike is whether the transmission of monetary policy through the so-called bank lending channel will be altered in strength when the Islamic segment of the banking sector becomes even more important. ${ }^{1}$ Indeed, the potency of the bank lending channel crucially depends on the ability of the central bank to affect bank loan supply, i.e., whether banks cannot attract (time) deposits perfectly elastically or do not consider the loans granted and securities held in portfolio as perfect substitutes.

Islamic banks may be, on the one hand, unable or unwilling to "buy" wholesale time deposits at a fixed rate and may not consider their Islamic loans substitutable for any of the securities they would hold in their portfolio. This may make the transmission of monetary policy shocks through the Islamic segment of the banking sector more potent. On the other hand, Islamic banks singularly attract deposits and lend under interest free arrangements, likely entered for religious reasons by depositors and borrowers (Khan and Khanna (2010); Baele, Farooq and Ongena (2010)). These contractual and motivational features on both their liability and asset sides may allow Islamic banks to shield themselves from monetary policy shocks (see Section 3). Consequently, whether

\footnotetext{
${ }^{1}$ This bank balance sheet channel may be operational because of agency problems between banks and their providers of funds, depositors, other debt-holders and equity holders (Bernanke (2007)). Gertler and Kiyotaki (2011) formalize this channel modeling financial intermediation as in Gertler and Karadi (2010) but include liquidity risk as in Kiyotaki and Moore (2008). The agency problems between banks and their borrowers (firms and households) give similarly rise to the firm balance-sheet channel (Lang and Nakamura (1995); Bernanke, Gertler and Gilchrist (1996); Bernanke, Gertler and Gilchrist (1999)). Gertler and Gilchrist (1993) and Oliner and Rudebusch (1996)for example find that, following the dates of monetary contractions identified in Romer and Romer (1989)), the ratio of bank loans to small versus large manufacturing firms falls. Gertler and Gilchrist (1994) show that, even after controlling for differences in sales between these firms, the differences in the behavior of small and large firm debt remain. If for firms bank loans are imperfectly substitutable with public financing, and prices adjust imperfectly, monetary policy affects real activity through the so-called credit channel.
} 
Islamic banks transmit monetary policy differently than conventional banks is an empirical question we aim to address in this paper.

Following Bernanke and Blinder (1992), who find that a monetary contraction is followed by a significant decline in aggregate bank lending, Kashyap and Stein (2000) analyze if there are important cross-sectional differences in the way that banks respond to monetary policy shocks. In this way controlling for loan demand, they find that following a monetary contraction, small banks with liquid balance sheets cut their lending less than other small banks. Brissimis, Kamberoglou and Simigiannis (2003), de Haan (2003), Kaufmann (2003), Loupias, Savignac and Sevestre (2003), Worms (2003), and Gambacorta (2005), for example, also find that liquidity positions of banks play a significant role for the way banks respond to a monetary shock in various European countries. Kishan and Opiela (2000), Jayaratne and Morgan (2000), Ashcraft (2006) and Black, Hancock and Passmore (2009) similarly examine the differentiation across bank capitalization, core deposits, bank holding company status and bank business strategies, for instance.

We follow the seminal paper by Kashyap and Stein (2000) by investigating the cross-sectional differences in the way that banks respond to monetary policy shocks not only across bank size and liquidity, but also across bank type, i.e., conventional versus Islamic, in Pakistan between 2002:II to 2010:I. The country and sample period provide a unique setting to analyze this differential response. Pakistan may be one of the few countries in the world where both well-developed conventional and Islamic banking sectors have co-existed for a considerable period, formally since 2002 whenIslamic Banking was re-introduced in Pakistan. Out of 40 banks that grant business loans, six are exclusivelyIslamic. 
As in Kashyap and Stein (2000) we find that following a monetary contraction, small banks with liquid balance sheets cut their lending less than other small banks, and that large banks maintain their lending irrespective of their liquidity positions.

Islamic banks, and this is the main contribution of our paper, though similar in size to small banks, respond to monetary policy shocks much like large banks. Hence, ceteris paribus, the expected growth in the Islamic segment of the banking sector in many countries may lead to a weakening in the potency of the credit channel of monetary policy there.

Khwaja and Mian (2008) also analyze lending by banks in Pakistan. They examine the drop in lending by different banks to similar firms following shocks to banks' liquidity induced by unanticipated nuclear tests that took place in 1998 in Pakistan. They find that banks pass their liquidity shortages to firms, but firms with strong business or political ties can turn to alternative sources in the credit market. In contrast, we focus on the monetary policy shocks responding to foreign capital inflows that followed this period and assess the differential transmission through the conventional and Islamic segments of the banking sector. Other studies that focus on the banking sector in Pakistan include Khwaja and Mian (2005), Mian (2006), and Zia (2008), for example.

The remainder of this paper is organized as follows. Section 2discusses the institutional framework in Pakistan after 2001 and its relevance for the lending channel. Section 3 describes the data and introduces the econometric specification and Section 4 discusses the results. Section 5 concludes. 


\section{Pakistan After 2001}

\section{a. Monetary Conditions}

Following 9/11 there was a substantial inflow of capital in Pakistan. Workers' remittances especially those from the US, UK, Saudi Arabia and UAE increased tremendously. Spurred by the privatization of major public sector corporations by the Government of Pakistan foreign direct investment (FDI) also boomed.

The growing inflow of remittances and FDI caused an appreciation in the local currency, the Pakistan rupee (PKR), against most other currencies. Prior to 2001, Pakistan had faced severe shortages in foreign reserves because of the nuclear tests in 1998 (Khwaja and Mian (2008)). The inflow of foreign capital was initially therefore welcomed. The State Bank of Pakistan (SBP), the nation's central bank, reacted to the inflow of foreign funds by purchasing US dollars and by increasingly accumulating these and other foreign reserves. Its aim was clearly also to curb the appreciation of the rupee against most other currencies to safeguard the competitiveness of Pakistanis exports. The purchase of dollars by the central bank almost inevitably caused the money supply to expand, despite attempts to sterilize the increase in money supply through the open market sales of government securities.

As a result, the financial markets in Pakistan became saturated with excess liquidity and in August 2003 the interest rate on government securities for example dropped to as low as 1.27 percent. It is only after 2005 that monetary policy started to tighten in response to inflation, inexorably following the relentless monetary expansion during the preceding years.

Since monetary policy during most of the analyzed time-period simply responded to this unique and large external shock, i.e., the concurrent inflow of remittances and FDI, 
our analysis will rely on the changes in the three-month Treasury bill rate as a most straightforward indicator of monetary policy. The use of variations in the short-term interest rate as a measure that proxies the change in the stance of monetary policy is fully in line with the literature analyzing the credit channel at the micro level. ${ }^{2}$ The use of a three-month interest rate follows many articles in Angeloni, Kashyap and Mojon (2003) for example that analyze European data. Replacing the changes in the threemonth interest rate with the changes in the overnight interbank interest rate or with the changes in the six-month Treasury bill rate yields very similar results, maybe not surprisingly as the correlation between all interest series is very high.

\section{b. Islamic Banks}

Preferably, Islamic banking is equity-, rather than fixed-interest-, based with profit and loss sharing on both the liability and asset side of a bank's balance sheet. Depositors in Islamic banks are for all practical purposes shareholders that receive no guarantee with respect to the face value of their "deposits". In principle, they fully share in the profits and losses of the bank in which they have their deposits. Similarly, on their asset side Islamic banks deploy an array of deferred sales, operational leases and profit and loss sharing arrangements to finance household consumption or firm investment. In many respects, Islamic banks are not unlike conventional mutual fund banks (e.g., Cowen and Kroszner (1990)).

Islamic banks seek funding through transaction deposits and investment accounts. Transaction deposits are similar to conventional banks' demand deposits, i.e., cash can

\footnotetext{
2 See Jayaratne and Morgan (2000), Kashyap and Stein (2000), Kishan and Opiela (2000), Ashcraft (2006) and Black, Hancock and Passmore (2009) among others. On the other hand, Bernanke and Blinder (1992) and Christiano, Eichenbaum and Evans (1996) use vector auto regressions to identify monetary policy shocks. However, Kashyap and Stein (2000) find very similar results using either the variation in the federal funds rate, the Boschen and Mills (1995) index or theBernanke and Mihov (1998) measure.
} 
be withdrawn at any time by writing a check or by accessing an automatic teller machine (ATM), and the bank guarantees the nominal value of the deposit. However, Islamic banks cannot lend the funds to projects that are Haram, i.e., not permissible under Islamic Jurisprudence and related to alcohol, pork, sex, etc., or that deal with interest payments (Riba), gambling (Maysar), or excessive uncertainty (Garrar). In general, Islamic banks aspire to be more conservative in lending.

Investment accounts are the equivalent of the conventional savings accounts plus time deposits. However, these accounts do not offer a fixed interest rate, but rather involve profit and loss sharing between bank and depositors. Although consequently the face value of the investment deposits is not ensured, Islamic banks invariably observe due diligence in financing various projects.

Joint venture financing arrangements constitute the most principled form of financing households and firms. However, in the early stages of their development, Islamic banks often adopt asset-backed fixed return arrangements, mainly deferred payment sales (Murabaha) and operational leases (Ijara), to finance household consumption, car purchases and real estate. In Pakistan these two types cover approximately 80 percent of the total financing provide by Islamic banks (as of December 2004), which has decreased to about 60 percent over time (as of December 2009). ${ }^{3}$

\section{c. Monetary Conditions and Islamic Banks}

The first Islamic bank in Pakistan was established in 2002 as a response to the until then - unmet market demand for Islamic financial products (Source: Financial

\footnotetext{
3 These two products are mainly replaced by another fixed-return scheme called diminishing Musharikah (i.e., "diminishing partnership"), in which the partner in an asset (a house for example) not only pays rental payments to the bank but over time also buys the share owned by the bank.
} 
Sector Assessment, SBP, 2004). Islamic banking quickly observed a sharp growth, as new and established banks entered the market by designing and offering suitable contracts to collect deposits from and extend credit to households and enterprises.

The main problem immediately faced by the Islamic banks was the absence of a government security designed in accordance with Islamic principles, for use as a safe investment or to fulfill the liquidity requirements set by the SBP. In the absence of such an Islamic government security, Islamic banks had no immediate base rate to price their Murabaha and Ijara contracts. Instead, they use the Karachi Interbank Offer Rate (KIBOR) (Source: Handbook of Islamic Products, SBP, 2009). However, the KIBOR is largely determined by the rate on short-term government securities such as the threemonth Treasury bill, which is set in fortnightly auctions. Because fixed return modes cover a large part of the total financing that is provided by Islamic banks, for the estimation of the strength of a lending channel the three-month Treasury bill rate can also be used as an indicator of the monetary policy stance.

The balance sheet data in Table 1 provide a first glimpse of the crucial differences between large and small conventional banks and Islamic banks in terms of liquidity for example. A large bank is defined as a bank with more than two hundred billion PKR (around 2.5 billion US dollar) in assets. According to this definition there are six large banks, representing around sixty percent of all banking assets. We label the remaining banks as small banks. By assets, all Islamic banks are small banks.

Liquidity is defined as the sum of cash, balances with Treasury banks and balances with other banks (as in Loupias, Savignac and Sevestre (2003) for example). Although the cash reserve requirement for both conventional and Islamic banks remained same through the entire sample period, liquidity varies noticeably across bank type. Small conventional banks are on average more liquid than large conventional banks during the 
period of easy monetary policy in 2003. However, the situation is reversed during the period of tight monetary policy after 2005. Hence, contractionary monetary policy creates more liquidity problems for small banks than for large banks. This is due to the fact that the large banks have relatively more options for nonreversible financing like debt or equity instruments.

In comparison with conventional banks Islamic banks have the higher fraction of their assets in cash and balances with Treasury and other banks. This is also the case in many other countries where Islamic banks are present (Beck, Demirgüç-Kunt and Merrouche (2010)). The explanation may be straightforward: In the early stages of their existence, Islamic banks had fewer immediate investment opportunities in comparison with their conventional counterparts.

Most of their liquidity remained in the form of cash and balances with other financial institutions. This is mainly due to the absence of a Shariah compliant instrument called Sukuk (Islamic bond), Islamic banks initially did not have any alternative investment option in securities. This is evident from the low fraction of their assets in investments in 2003 (Table 1). The first compliant instrument was issued by a public sector enterprise only in 2005 but it could not fulfill the large investment appetite of Islamic banks. So until 2008, and in the absence of any Islamic government security, Islamic banks held cash to fulfill the statutory liquidity and cash reserve requirements (SLR).

Holding only cash resulted in higher opportunity costs for Islamic banks than for conventional banks. Realizing that Islamic banks were at a cost disadvantage compared to conventional banks in meeting the SLR, the SBP relaxed it for Islamic banks. While their cash reserve requirements are the same, Islamic banks, on average, have been required to hold ten percent less in SLR than the conventional banks. During the period under study, Islamic banks need to hold nine percent of the total demand and time 
deposits for SLR purpose, whereas conventional banks are liable to maintain nineteen percent of demand and time deposits (Table 2). Therefore, and in order to make our analysis comparable across bank type, we take the liquidity variable equal to the first two liquidity items, i.e., cash and balances with Treasury and other banks, for which the requirements and the opportunities are likely most similar for conventional and Islamic banks.

In the absence of a risk-free Islamic instrument, Islamic banks also benchmarked their fixed-return contracts, Murabaha and Ijara, to the conventional interest rate charged in the interbank market, which is usually based on the Treasury-bill rate. However, the loan supply of Islamic banks is less likely to react to changes in monetary policy because as said they have fewer investment opportunities and are more likely to sit on a lot of spare liquidity. In addition, since Islamic banks assets are only indirectly linked to the policy rate, Islamic banks are less affected by the changes in monetary policy.

\section{d. Bank Lending Channel in Pakistan}

The structure of a country's banking system is likely to determine the strength of the response of bank lending to monetary policy shocks. The size of the banking sector and its market concentration, the fraction of banking assets that are liquid, and the banks' capitalization could be crucial in establishing the potency of the bank lending channel.

State and foreign ownership of domestically operating banks will also be important in determining the impact of domestic monetary policy on bank loan supply. State owned banks, that are mostly publicly guaranteed, likely attract new funds elastically to offset the impact of monetary contractions for example (Ehrmann, Gambacorta, Martinez-Pagés, Sevestre and Worms (2003)). Similarly, foreign banks with close links 
to their parent institutions and global bank networks are likely to absorb the impact of domestic monetary policy without altering their domestic loan supply (foreign banks with most of their funding in their home country may contract lending relatively more following contractionary monetary policy in their home country).

This section presents salient features of the banking system in Pakistan, such as the importance of banks within the financial system and corporate finance, the market structure, the heterogeneity of the banks, their overall performance and the role of the state in the banking system. Each of these features may determine the potency of the bank lending channel. Tables 3 and 4 provide many of the statistics we now discuss, while Table 5 summarizes how the various characteristics we will discuss determine the potency of the bank lending channel in Pakistan.

\section{i. Importance of Banks within the Financial System}

Banks play a central and still expanding role in the financial system of Pakistan. In the wake of reforms, that started during 1990s and which included bank privatizations and interest rate liberalization for example, the total assets of the banking system increased during the last decade, both in absolute value and as a share of the total assets of the financial system, from 65 percent in 2002 to 74 percent in $2009 .^{4}$

In contrast, the share of nonbank financial institutions and the Central Directorate of National Savings decreased from 6.2 to 5.6 and from 25 to 17 percent, respectively. The latter category of financial institutions comprises various national saving schemes through which the government mobilizes household savings by offering various debt instruments at varying maturities and constitutes a major source of nonbank borrowing

\footnotetext{
${ }^{4}$ The banks also own shares in nonbank financial institutions, insurance companies, brokerage houses, and financial advisory services further underlining their central role in the financial system (Source: Financial Stability Review 2007-08, SBP).
} 
for the government. The minute share of microfinance and insurance institutions increased slightly.

In general, global macroeconomic and political developments remain favorable to the Pakistani banking sector. Yet, total private sector credit granted by banks over gross domestic product (GDP) expanded briskly until 2005, but then leveled off, and for the first time dropped in 2007 , corresponding to the tightening of monetary conditions and suggestive of the existence of a lending channel in Pakistan.

ii. Importance of Banks for the Financing of Corporations

Banks around the world are very important in fulfilling the financing needs of the corporate sector. Public debt and equity play, for most firms and even in financially well developed countries, only a minor role in financing corporate activities.

Debt and equity markets are often found to be less developed and subject to more intense market imperfections in emerging economies. This is also the case in Pakistan. The issuance of public debt is very limited, and especially small firms rely heavily on bank debt. Bond market capitalization has even decreased over time in nominal terms. Stock markets continue to play a modest role in corporate sector funding. Stock market capitalization has shown an upward trend, but still the market is relatively thin, dominated by a handful of commercial banks' stocks, and mainly driven by the demand from foreign investors.

In sum, banks play a dominant role as financial intermediaries in Pakistan. If the supply of bank loans to firms changes following changes in monetary policy, firms likely will be affected as for most firms financing alternatives may not be readily available. 


\section{iii. Performance of the Banking Sector}

The transmission of monetary policy will also depend on the performance of the banks. Stronger banking sector results in a weaker effect of monetary policy on the loan supply (Cecchetti (1999)). The financial strength of the banking system can be measured through asset quality, capital adequacy, liquidity and the earnings of the banking system.

The first half of the sample period is characterized by an increase in the stability and expansion regarding banking system. Banking business remained profitable and return on equity (ROE) for example grew until 2006. Similarly, the cost - income ratio dropped until the same year.

However, after the tightening of monetary policy started in 2005, performance of the banking sector weakened and in subsequent years there was a rise in non-performing loans and a resultant erosion of capital. The banking sector in Pakistan is clearly not immune to contractionary monetary policy shocks, as bank balance sheets are affected by the increasing interest rates.

\section{iv. Relationship Lending}

A strong relationship with a bank may insulate an individual firm to some extent from the cut in bank lending that follows a contractionary monetary policy. This shielding may not only be vis-á-vis other firms that have no relationship, but also across time if banks would intertemporally "subsidize."

If firms engage multiple banks, firms can switch if one bank is affected more by contractionary monetary policy than the others (Detragiache, Garella and Guiso (2000)). Large firms are mostly immune from any type of financing shortage by switching 
among banks when needed (Khwaja and Mian (2008)). Small firms however are often unable to substitute between banks, or between bank and other type financing.

\section{v. Market Concentration and Size Structure}

Informational frictions in the banking sector are important for the lending channel to operate. If market players in the interbank markets are facing significant informational asymmetries, then distributional effects are likely to occur between banks that are confronted with informational issues to various degrees. Size criterion is used as standard in literature as a proxy to measure the informational opaque situation of banks. Small banks, in general, are considered to be more exposed to informational frictions than large banks. Therefore, the external finance premium for the former category is probably higher than for the latter group.

The banking market is characterized by a steadily decreasing concentration during the sample period. The Herfindahl-Hirschman Index (i.e., the sum of market shares squared) decreased from 973 in 2002 to 736 in 2008, while the C-5 (the market share of the five largest banks by total assets) dropped from 61 to 52 percent. The group of the largest banks (with total assets more than 200 billion PKR) slipped from 65 percent in 2004 to 52 percent in 2008. As concentration dropped, competition may have intensified, possibly making the bank lending channel more potent.

\section{vi. State Influence in the Banking Sector}

Before the financial reforms in 1990s, the Pakistani financial system was mainly characterized by high government borrowing, bank-level credit ceilings, directly controlled interest rates, and directed and subsidized loan supply.

Public ownership of banks was introduced in the 1970s and lasted until the early 1990s, making the state all dominant in the banking sector. In 1990 there was not a 
single domestic private bank.However, due to additional privatization of state-owned banks during the sample period studied, the influence of the state has been waning. The fraction of assets of state-owned banks over total assets of the banking system halved from 52 percent in 2002 to 26 percent in 2009 potentially strengthening the banking lending channel of monetary policy transmission.

\section{vii. Deposit Insurance}

There is no deposit insurance in Pakistan. Rather, deposits are in principle indirectly insured only by the continuous supervision by the regulatory authority. Detailed prudential regulations have been issued to avoid different types of risks a bank could be exposed to. Moreover, stringent liquidity requirements are in place to restrain banks to take excess leverage.

Therefore, in absence of explicit deposit insurance the lending channel may be more potent, because the lack of certainty about the nominal value of deposits makes depositors feel unsafe about their money. Consequently, following a tightening of monetary policy, deposits may be withdrawn and banks compelled to cut lending.

\section{viii. Bank Failures}

There were few bank failures in Pakistan during the 1990s. Some institutions became involved in scandals and failed due to imprudent banking. The Mehran Bank scandal is well-known, for example. Some banks were involved in a few scandals causing depositors to feel insecure. Furthermore, some cooperative societies also collected deposits from the people with a promise of higher returns than the ongoing market rates. These societies inevitably failed and caused a loss for their depositors.

Due to these incidents in the past, there may be a higher occurrence of rumors and an abrupt contraction in deposits following a tighter monetary policy. Furthermore, fraud 
and forgeries independently affect deposits, which in turn affect lending of the banks. Data related to such cases indicate a significant increase in such cases during the last few years (Source: Financial Stability Review 2008-09, SBP).

\section{ix. Foreign Banks and Bank Networks}

In case any liquidity problem arises, due to a decrease in demandable deposits, foreign banks and banks in networks can resort to their head office or holding company to cover the liquidity shortage. Under this scenario, the potency of the bank lending channel of domestic monetary policy transmission becomes weaker. The role of foreign banks has been limited in Pakistan, i.e., they account for only ten percent of total banking sector assets. There are some implicit bank networks in Pakistan in that ownership of some banks is common. There is also foreign ownership in some large banks. However, evidence strongly suggests banks in Pakistan do pass shocks to their liquidity position to their borrowers (Khwaja and Mian (2008)). This evidence, combined with the weak role of foreign banks and bank networks, makes it more likely that tight monetary policy eventually leads to the loss of deposits by the banks and a contraction in lending.

\section{Data and Econometric Specification}

The main source of data is the Quarterly Report of Conditions (QRCs) of all banks submitted to the State Bank of Pakistan (SBP). The data set covers the whole population of all banking institutions that is operational in the financial system and incorporates their QRCs' figures. The time period is from 2002:II to 2010:I at a quarterly basis. There are 40 banks, of which six are Islamic Banks. 
We lose observations because: (1) Some banks start operating after 2002:II; (2) we employ up to four lags of quarterly growth rates; (3) some banks merge and following Kashyap and Stein (2000) we remove banks' observations in any quarter in which they are involved in a merger; (4) we remove observations for which the loan growth rate is more than three standard deviations from its sample mean; (5) there are missing values in the dataset. We are left with 756 bank - year: quarter observations that can be used in the estimations.

For our analysis of banking lending channel, we use the model by (Ehrmann, Gambacorta, Martinez-Pagés, Sevestre and Worms (2001)), which is a for our purposes relevantversion of the Bernanke and Blinder (1988) model. There is no fundamental change in the model when it isapplied to Islamic banks. We explain the model with respect to conventional banks compared with Islamic banks. The money market equilibrium can be described as follows:

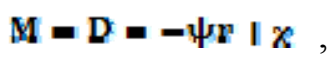

where deposits (D) are considered to be money (M), depends negatively on the risk free government bonds' interest rate, being the opportunity cost of holding money. Due to the religious motivations, $\psi$ is expected to be much lower for Islamic banks than for conventional banks (Khan and Khanna (2010)).

The demand for loans $\mathbf{L}_{\mathbf{i}}^{\mathbf{d}}$ which a bank faces is assumed to depend on the interest rate on loans $\left(\mathrm{r}_{1}\right)$ :

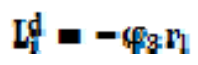

Equation (2) can alsoapply to Islamic banks as Islamic banks indirectly use government treasury bill rate as bench mark for their products for financing (Source: Handbook of Islamic Products, State Bank of Pakistan, 2009). 
The supply of bank loans ( $\left.\mathbf{L}_{\mathbf{i}}^{\boldsymbol{s}}\right)$ depends on the amount of money (or deposits) available and interest rate on loans. $\mathbf{L}_{\mathbf{i}}^{\mathbf{S}}$ also depends (negatively) on the monetary policy rate directly, as the same is considered to be the opportunity cost of bank loans on their assets side as well as the cost of interbank financing on the liability side of the banks' balance sheet. The function remains the same as Islamic banks areexpected to behave as the conventional banks:

$$
L_{i j}=H_{i} D_{i}+\varphi_{4} D_{l}-\varphi_{p} r
$$

It is also assumed that the impact of change of monetary policy through deposits is lower, the higher the bank liquidity $\left(\mathbf{x}_{1} \mathfrak{D}\right)$ is:

$$
S_{1}=\mu_{0}-\mu_{1} x_{1}
$$

In comparison with conventional banks, Islamic banks are more liquid because of the limited financing avenues in the initial stage of their operations.

Inserting (1) and (2) into (3) we get:

$$
L_{i}=\left(\mu_{G}-\mu_{1} x_{D}\right)(-\psi r+\chi)+\varphi_{4} p_{1}-\varphi_{p} r
$$

Also from (2) we get $\mathbf{r}_{1}$ :

$$
\nu_{1}=\frac{\left(\varphi_{1} \mathrm{Y}+\varphi_{2 \mathrm{~F}}-\mathrm{L}^{\mathrm{d}}\right)}{\varphi_{9}}
$$

We substitute (2a) into (3a) to get:

$$
L_{i}=\left(\mu_{0}-\mu_{1} x_{1} X-\psi r+\chi\right)+\frac{\varphi_{A}(-L d)}{\varphi_{3}}-\varphi_{p} r
$$

Since in equilibrium: $L_{i}^{d}=L_{i}=L_{k}$, we replace the values accordingly and solve for L:

$$
L_{i}=\left(\mu_{q}-\mu_{1} x_{i}\right)(-\psi r+\chi)+\frac{\varphi_{4}\left(-L_{i}\right)}{\varphi_{i j}}-\varphi_{i} r
$$

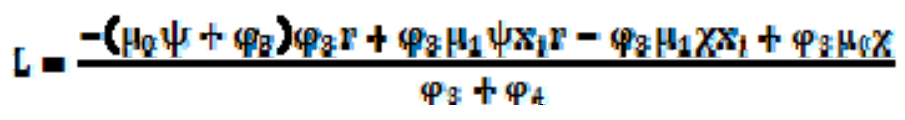

Hence: 
Where $\mathfrak{s}_{1}=\frac{\varphi_{9} \boldsymbol{P}_{14}}{\varphi_{y} \mathrm{I} \varphi_{4}}$ is the coefficient ontheinteraction termof liquidity and the policy rate, and it captures the banks' response to a monetary shock depending upon their liquidity position. A statistically significant and economically relevant $\mathbf{c}_{\mathbf{1}}$ implies that monetary policy does affect the loan supply. In our robust estimation we control for the demand side impact as well by interacting liquidity with the large-scale manufacturing index. A priori, Islamic banks seem to be not responsive to monetary policy conditionsbecause of (i)the religiosity of their depositors and (ii) their strong liquidity position. For estimation, we introduce some dynamics in thefinal equation and closely follow Kashyap and Stein (2000). The methodology, in general, is based on an assessment of the differences in the response of individual banks to a monetary policy shock according to their liquidity positions.

In sum, we estimate the following Equation(5):

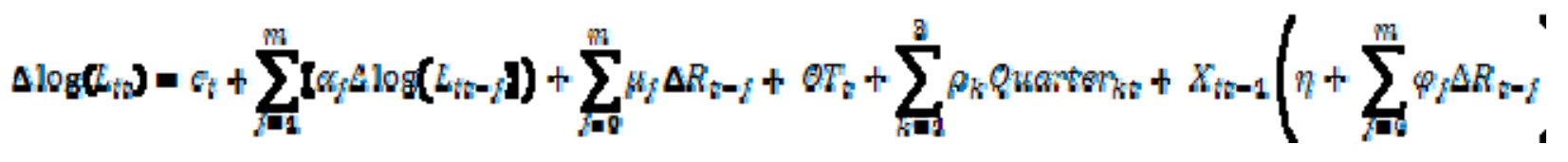

Where,

$\varepsilon_{i}=$ bank $i$ specific fixed effect,

$\Delta \log \left(L_{i n-2}\right)=$ the quarterly change in the logarithm of the total amount of the loans granted to the private sector by bank $i$ in year: quarter $t-j$,

$\Delta R_{i-f=}=$ the quarterly change in the three-month Treasury bill rate in year: quarter $t-j$, $T_{t}=$ time trend,

Quarter $_{k t}=$ dummy for quarter $k$ in year: quarter $t$, and

$X_{\text {th-1 }}=$ liquid assets (i.e., cash and balances with the banks) over total assets of bank $i$ in year: quarter $t$. 
$m$ is set to equal four, i.e., one calendar year. This corresponds to the number of lags used in other papers assessing the potency of the credit channel in other countries.

The cross-sectional and time-series derivatives of Equation (5) explain the correspondencewe assess in the data. The cross-sectional derivative, $\frac{\partial L_{t}}{\partial X_{t}=1}$, determines the sensitivity of bank i's lending to its liquidity position in the last quarter. The time-series derivative, $\frac{a L_{t}}{a R_{2}}$, captures the sensitivity of lending of bank $i$ to monetary impulses. This derivative establishes the direct responsiveness of bank lending to monetary policy on average, irrespective of individual bank characteristics.

We want to test how the sensitivity of bank lending to monetary policy of an individual bank depends on its liquidity position which can be capture through second

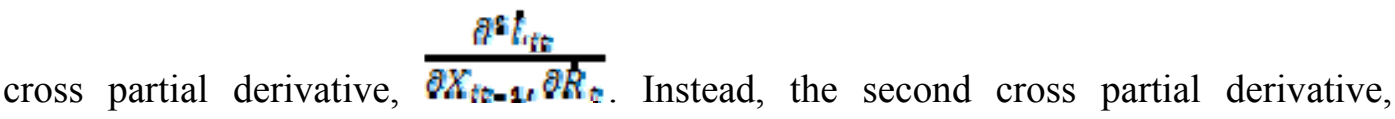

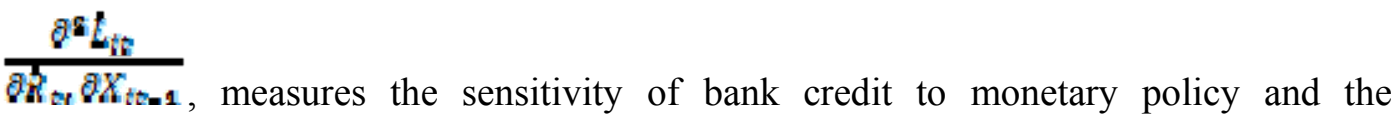
hypothesis is that this sensitivity is higher for banks with weak liquidity positions. Both thesederivatives usethe cross-sectional and time-series properties of the data.

The main hypothesis is that contractionary monetary policy affects the small illiquid banks more than the liquid banks, as the latter can offset any decrease in deposits by reducing their liquid assets. Consequently, our main coefficient of interest is the sum of interaction terms of liquidity $X_{i t-1}$ with the monetary policy measure $\Delta R_{t-j}$, i.e., $\sum \varphi$. The correctness of the aforementioned hypothesis requires this coefficient to be positive and statistically significant, i.e., lending by small liquid banks is less sensitive to a monetary shock than lending by other small banks. 
Equation (5) is first estimated for the entire banking sector to evaluate the potency of the aggregate bank lending channel. Large banks are possibly less influenced than small banks by monetary shocks because of their ability to raise time deposits, which irrespective of their internal liquidity positions - would make their lending less dependent on monetary policy shocks. Islamic banks may also be less affected. Therefore, we also estimate Equation (5) including dummies both for large banks and Islamic banks. Both dummies are interacted then with all coefficients, except the trend, quarter, and province shares. We also replace the bank-specific effects with these province shareswhich are constructed by calculating for each bank the relative number of branches it has in each province.

In robustness, and to further control for the business cycle and loan demand, we also include change in the large-scale manufacturing index (LSM). Equation (6) equals:

\section{Results}

\section{a. All Banks}

Table 7 presents the results of the baseline regression, i.e., Equation (5), estimated using the observations of all banks. The purpose is to assess the potency of the bank lending channel for the overall banking sector. The table shows the sum of the estimated coefficients. The coefficients for provinces, quarter dummies and time trend are not shown. All estimates are in percentage terms and heteroscedasticityrobust standard errors. 
The estimated coefficients confirm that the bank lending channel is operational in Pakistan. The sum of the estimated coefficients on the changes in the three-month Treasury bill rate equal $-5.83 * * *{ }^{5}$ Hence, an increase in the interest rate by one percentage point decreases loan growth by 5.83 percentage points.

To identify that this decrease in loan growth actually represents a contraction in the supply of credit and not a reduction in the demand for credit, we interact the measure for bank specific liquidity with the interest rate (as in Kashyap and Stein (2000)). The sum of the estimated coefficients on this interaction term equals $20.71^{*}$. Consequently, banks with a higher level of liquidity contract lending less following a monetary shock (we discuss the economic relevancy of similar estimates in the next table).

To check the robustness of these estimates we replace the three-month Treasury bill rate with the KIBOR in Model (3) and the six-month Treasury bill (results not shown). The sum of the estimated coefficients on the changes in the interest rates equal $-3.69 * * *$ and $-5.12 * * *$, respectively, while the sum of the estimated coefficients on the interaction term with liquidity equal 20.71 and 15.42 . Individual liquidity coefficients are insignificant for all specifications.

To control better for regional effects Model (4) replaces the bank fixed effects with bank province shares, i.e., for each bank the number of branches it has in each province divided by the total number of branches it has. To control better for business cycle and loan demand Model (5) includes the change in industrial production. Estimates are mostly unaffected.

\footnotetext{
${ }^{5}$ As in the Tables we star (the sum of) the estimated coefficients according to their significance levels. $* * *$ Significant at $1 \%, * *$ significant at $5 \%, *$ significant at $10 \%$.
} 


\section{b. Large and Islamic Banks}

We now assess the role played by large and small (conventional) banks, and Islamic banks in the bank lending channel. We interact dummies for Large and Islamic banks with all independent variables (except with for the trend, season and province shares). Table 8 exhibits the results for various specifications.

The baseline Model (4) indicates especially the small banks make the bank lending channel operational, a finding also present in Kashyap and Stein (2000). An increase in the three-month Treasury bill rate of one percentage point decreases the loan growth of small banks by $7.17^{* * *}$ percentage points in a year. The sum of the estimated coefficients on the interaction terms of liquidity and interest rates equal $25.06^{* * *}$.

To assess if the estimated coefficients also have economically relevant implications, we need to calculate the response in lending by similarly sized banks, but different liquidity positions, to a monetary policy shock. Using the liquidity distribution of small banks in 2010:I, we consider a bank at the $9^{\text {th }}$ decile as a 'liquid' bank and at the $1^{\text {st }}$ decile as an 'illiquid' bank. The liquidity ratios according to this criterion are 24 and 5 percent, respectively. Under this scenario, a one percentage point increase in the interest rate reduces the lending by an illiquid bank 4.5 percentage points more than the lending by a liquid bank over one year time period. This is calculated through multiplying $\sum \varphi$ by liquidity differential of the liquid and illiquid banks i.e. $25.06 \times$ $(0.24-0.05)$.

The estimated results for the large banks are different. The sum of the estimated coefficients on the change in interest rate is positive, i.e., $7.06^{*}$, but only marginally significant. Hence, large banks are not sensitive to changes in monetary policy due to their ability to fund their lending from the market other than deposits. The sum of the interaction terms of liquidity and the interest rate is now negative, as in Kashyap and 
Stein (2000), but insignificant. Using the difference between small banks and large banks coefficient there is 12.2 percent gap in the level of lending across liquid and illiquid small banks one year after a monetary shock.

All in all, these findings are very similar to those in Kashyap and Stein (1995), i.e., tight monetary policy decreases the loan growth of small banks but may actually increase credit granted by large banks in the short run. Romer and Romer (1990), Bernanke and Blinder (1992), and Christiano, Eichenbaum and Evans (1996) also show that credit reacts sluggishly or initially even expands following a monetary tightening. In Pakistan this effect is also present due to the response of the large banks.

Islamic banks are equivalent to small banks in terms of asset size and as Islamic banks use the conventional interest rate as a key benchmark, one can expect that the bank lending channel will also operate through Islamic banks. However, since Islamic banks were expanding during the sample period, their deposit growth may have been less affected by tight monetary policy. Also, share of their fixed deposits in total deposits is higher than conventional banks. Using panel data of bank deposits across all commercial banks in Pakistan, Khan (2010) also found that Islamic banks enjoy substantially higher deposit growth rates than other banks including the crises period of 2008. Moreover, the liquidity position of the Islamic bank makes them less susceptible to a change in the interest rate.

The results indeed show that the loan growth of Islamic banks is not affected by changes in the interest rate. The sum of the estimated coefficients equals, 2.05, positive but not statistically significant. Similarly, the sum of the estimated coefficients on the interaction terms of bank liquidity and changes in the interest rate equal -31.83 , negative and insignificant. In both cases Islamic banks are statistically different from small banks 
with an estimated difference that equals $9.22 *$ for the changes in the interest rate and $56.90^{* * *}$ for the interaction term, but similar to the large banks.

As before, and to check the robustness of these estimates, we replace the three-month Treasury bill rate with the KIBOR in Model (3) and the six-month Treasury bill rate (results not shown), and introduce bank province shares and the change in large-scale manufacturing in Models (4) and (5). Results are mostly unaffected and document that even though Islamic banks are small (in terms of asset size), their response in lending to a monetary policy shock is similar to that of the large banks in the sample. We further testwhether there is any significant difference in lending response of banks to contractionary monetary policy and expansionary monetary policy. The results show that the difference in banks' lending response to both phases of monetary policy is insignificant.

A fixed effects model may create a correlation between lagged dependent, $\Delta E_{i t-1}$ and the error term, causing the "Nickel bias" as described in for exampleVerbeek (2008).However, this bias is expected to be negligibleif the time period is substantial (Judson and Owen (1999)). In our case it is32 quarters, which is sufficiently large.Nevertheless, to ensure the validity of our results we also estimateEquation (5) using two-stage least square method (first-stage GMM). Specifically, we employthesecond lag of the dependent variable in level form as an instrument for the first lag of the dependent variableand estimate Equation (5)with the Arellano and Bover (1995)approach. The instruments used are valid according to Sargan test. There is only a verysmall change in results.

We also check the robustness of our results by changing the measure of liquidity. Specifically we used liquid assets to deposits ratio as liquidity measure instead of liquid 
assets to total assets ratio. This measure incorporates the changes in the deposits as a result of monetary policy impulses. The new estimates corroborate the earlier findings.

\section{Conclusion}

We investigate the differences in banks' responses to monetary policy shocks across bank size, liquidity, and type, i.e., conventional versus Islamic, in Pakistan between 2002:II to 2010:I. We find that following a monetary contraction, small banks with liquid balance sheets cut their lending less than other small banks. In contrast large banks maintain their lending irrespective of their liquidity positions. Islamic banks, though similar in size to small banks, respond to monetary policy shocks like large banks. Hence the credit channel of monetary policy may weaken when Islamic banking grows, with their current portfolio under conventional monetary policy, in relative importance.

However, if there are (1) sukuk issued that can be used as a monetary policy indicator for Islamic banks, (2) more investment opportunities available for Islamic banks, (3) an efficient Islamic interbank market, and (4) a competitive Islamic banking industry then the credit channel through Islamic banks may start gaining in potency to the extent that some Islamic banks remain small and hence face funding constraints. 


\section{Table 1: Balance Sheet Items for Conventional Banks and Islamic Banks}

Balance sheet items for conventional banks and Islamic banks as a percentage of assets and liabilities, and indicated items.

\begin{tabular}{|c|c|c|}
\hline \multicolumn{2}{|c|}{ Conventional Banks } & $\begin{array}{c}\text { Islamic } \\
\text { Banks }\end{array}$ \\
\hline Large Banks & Small Banks & \\
\hline 2003 & $2003 \quad 2009$ & 2003 \\
\hline
\end{tabular}

\section{Assets}

Cash and Balances With Treasury Banks

$\begin{array}{llllll}10 & 10 & 9 & 6 & 12 & 8\end{array}$

Balances With Other Banks

Lending To Financial Institutions

$\begin{array}{llllll}4 & 3 & 4 & 2 & 12 & 7\end{array}$

.

Investments - Net

Call Money

Repurchase Agreements

Other

7

811

3

$86 \quad 84$

$\begin{array}{llllll}6 & 6 & 11 & 21 & 0 & 98\end{array}$

\begin{tabular}{|c|c|c|c|c|c|c|}
\hline Investments - Net & 36 & 25 & 22 & 31 & 7 & 16 \\
\hline Market Treasury Bills & 69 & 51 & 49 & 67 & 0 & 5 \\
\hline Pakistan Investment Bonds & 19 & 9 & 43 & 14 & 0 & 2 \\
\hline Other & 12 & 40 & 8 & 19 & 100 & 93 \\
\hline Advances - Net & 37 & 52 & 50 & 45 & 64 & 44 \\
\hline Other Assets & 6 & 8 & 5 & 12 & 4 & 9 \\
\hline \multicolumn{7}{|l|}{ Liabilities } \\
\hline Borrowing From Financial Institutions & 5 & 6 & 22 & 17 & 12 & 4 \\
\hline Deposits and Other Accounts & 84 & 78 & 66 & 64 & 69 & 80 \\
\hline Time Deposits & 18 & 28 & 23 & 38 & 42 & 42 \\
\hline Saving Deposits & 50 & 36 & 54 & 33 & 46 & 31 \\
\hline Current Accounts & 31 & 36 & 23 & 28 & 12 & 26 \\
\hline Subordinated Loans & 0 & 1 & 1 & 1 & 0 & 0 \\
\hline Other Liabilities & 5 & 4 & 6 & 7 & 4 & 5 \\
\hline Equity & 5 & 10 & 6 & 10 & 15 & 10 \\
\hline
\end{tabular}

Source: Annual audited bank accounts. 
Table 2: Statutory Cash and Liquidity Reserve Requirements

Statutory cash and liquidity reserve requirements as a percentage of time and demand deposits.

\begin{tabular}{cccc} 
& Cash Requirements & \multicolumn{2}{c}{ Liquidity Requirements } \\
\hline Dates & All Banks & $\begin{array}{c}\text { Conventional } \\
\text { Banks }\end{array}$ & Islamic Banks \\
\hline Until 2006 & 5 & 15 & 6 \\
Feb 15, 2006 & 5 & 15 & 8 \\
July 18, 2006 & 5 & 15 & 8 \\
July 18, 2006 & 7 & 18 & 8 \\
June 31, 2008 & 8 & 18 & 8 \\
May 22, 2008 & 9 & 19 & 9 \\
Oct 17, 2008 & 6 & 19 & 9 \\
Nov 1, 2008 & 5 & 19 & 9 \\
\hline
\end{tabular}


Table 3: Financial Intermediation in Pakistan in 2002 - 2009

\begin{tabular}{|c|c|c|c|c|c|c|c|c|}
\hline & 2002 & 2003 & 2004 & 2005 & 2006 & 2007 & 2008 & 2009 \\
\hline \multicolumn{9}{|l|}{ As a Share of Total Assets of Financial Sector } \\
\hline Microfinance Institutions & 0.1 & 0.1 & 0.1 & 0.2 & 0.2 & 0.2 & 0.2 & 0.2 \\
\hline Nonbank Financial Institutions & 6.2 & 6.6 & 7.0 & 7.6 & 7.8 & 8.0 & 7.6 & 5.3 \\
\hline Insurance & 3.8 & 3.8 & 3.8 & 3.9 & 4.1 & 4.6 & 4.4 & 4.4 \\
\hline Central Directorate of National Savings Institutions & 24.9 & 25.0 & 21.7 & 18.0 & 16.1 & 14.6 & 14.8 & 16.6 \\
\hline Banks & 65.0 & 64.5 & 67.3 & 70.4 & 71.9 & 72.7 & 73.0 & 73.5 \\
\hline \multicolumn{9}{|l|}{ As a Percent of Gross Domestic Product } \\
\hline Microfinance Institutions & 0.1 & 0.1 & 0.1 & 0.1 & 0.1 & 0.1 & 0.1 & 0.1 \\
\hline Nonbank Financial Institutions & 4.6 & 4.9 & 5.2 & 5.6 & 5.7 & 5.9 & 5.0 & 3.4 \\
\hline Insurance & 2.8 & 2.9 & 2.8 & 2.9 & 3.0 & 3.4 & 2.9 & 2.8 \\
\hline Central Directorate of National Savings Institutions & 18.2 & 18.8 & 16.1 & 13.3 & 11.7 & 10.8 & 9.8 & 10.8 \\
\hline Banks & 47.7 & 48.3 & 50.1 & 51.8 & 52.4 & 53.9 & 48.1 & 47.6 \\
\hline All & 73.3 & 75.0 & 74.4 & 73.7 & 72.9 & 74.1 & 66.0 & 64.7 \\
\hline Private Sector Credit & 18.0 & 19.9 & 22.6 & 26.3 & 27.8 & 28.5 & 27.6 & 22.8 \\
\hline
\end{tabular}

Source: State Bank of Pakistan. 
Table 4: Banking Structure in Pakistan in 2002 - 2009

\begin{tabular}{llllllll}
2002 & 2003 & 2004 & 2005 & 2006 & 2007 & 2008 & 2009 \\
\hline
\end{tabular}

\section{Public Debt and Stock Market Financing}

Domestic Debt Securities Issued by the Corporate Sector, in \% of GDP

$\begin{array}{rrrrrrrr}0.19 & 0.05 & 0.08 & 0.16 & 0.04 & 0.07 & 0.25 & 0.02 \\ 1.50 & 0.30 & 0.40 & 0.60 & 0.20 & 0.30 & 0.90 & 0.10 \\ 14 & 20 & 30 & 42 & 36 & 49 & 14 & 20 \\ & & & & & & & \\ 21 & 35 & 31 & 37 & 36 & 23 & 11 & 13 \\ 67 & 59 & 63 & 72 & 71 & 68 & 70 & 72 \\ & & & & & & & \\ 973 & 912 & 850 & 762 & 745 & 739 & 736 & 712 \\ 1.7 & 1.6 & 1.5 & 1.4 & 1.4 & 1.4 & 1.4 & 1.4 \\ 61 & 59 & 56 & 54 & 52 & 52 & 52 & 51 \\ \mathrm{n} / \mathrm{a} & \mathrm{n} / \mathrm{a} & 65 & 64 & 60 & 58 & 59 & 57\end{array}$

Domestic Debt Securities Issued by the Corporate Sector, in \% of Bank Loans to Corporate Sector

Stock Market Capitalization, in \% of GDP

\section{Bank Performance}

ROE (Profit after Tax over Capital and Reserves), in \%

Cost Income Ratio, in \%

Measures of Banking Sector Concentration

Herfindahl-Hirschman Index

Coefficient of Variation

Assets of Largest 5 Banks, in \% of Total Bank Assets

Assets of Large Banks (Assets > 200 bln. PKR), in \% of Total Bank Assets

State Ownership

Assets of the Public Sector Banks, in \% of Total Bank Assets

\begin{tabular}{llllllll}
52 & 49 & 27 & 26 & 26 & 27 & 25 & 26 \\
\hline
\end{tabular}

Source: State Bank of Pakistan. 


\section{Table 5: Factors Determining the Potency of the Bank Lending Channel}

This table provides the factors that determine the potency of the bank lending channel and the direction of their impact.

\begin{tabular}{|c|c|c|}
\hline Factor & Strengthening & Weakening \\
\hline \multicolumn{3}{|l|}{ Importance of the banking sector } \\
\hline Importance of bank financing & $\checkmark$ & \\
\hline Investors protection and capital markets & $\checkmark$ & \\
\hline Bank dependence & $\checkmark$ & \\
\hline \multicolumn{3}{|l|}{ Structure of the banking system } \\
\hline Concentration and size & & $\checkmark$ \\
\hline Financial strength & $\checkmark$ & \\
\hline State influence & $\checkmark$ & \\
\hline Foreign ownership and bank networks & $\checkmark$ & \\
\hline \multicolumn{3}{|l|}{ Regulatory requirements } \\
\hline Capital adequacy & & $\checkmark$ \\
\hline Deposit insurance & $\checkmark$ & \\
\hline Bank failures & $\checkmark$ & \\
\hline
\end{tabular}




\section{Table 6: Descriptive Statistics}

This table provides the definitions, means, standard deviations, minimum and maximum of all variables used in the estimations. All variables are expressed in percent. The number of bank - year: quarter observations equal 756.

\begin{tabular}{|c|c|c|c|c|c|c|}
\hline Variable Name & Definition & Bank Type & Mean & $\begin{array}{r}\text { Standard } \\
\text { Deviation } \\
\end{array}$ & Minimum & Maximum \\
\hline Small Bank & $\begin{array}{l}=1 \text { if the bank has average total assets below } 200 \mathrm{bln} . \text { PKR and } \\
\text { is a conventional bank, }=0 \text { otherwise }\end{array}$ & 28 banks & 0.70 & 0.46 & 0 & 1 \\
\hline Large Bank & $\begin{array}{l}=1 \text { if the bank has average total assets exceeding } 200 \mathrm{bln} . \mathrm{PKR} \\
\text { and is a conventional bank, }=0 \text { otherwise }\end{array}$ & 6 banks & 0.15 & 0.36 & 0 & 1 \\
\hline Islamic Bank & $=1$ if the bank is classified as an Islamic Bank, $=0$ otherwise & 6 banks & 0.15 & 0.36 & 0 & 1 \\
\hline
\end{tabular}




\begin{tabular}{|c|c|c|c|c|c|c|}
\hline Variable Name & Definition & Bank Type & Mean & $\begin{array}{r}\text { Standard } \\
\text { Deviation }\end{array}$ & Minimum & Maximum \\
\hline \multirow{4}{*}{$\Delta \log \left(t_{t}\right)$} & \multirow{4}{*}{ Change in the log of private sector loans } & All Banks & 4.2 & 12.6 & -57.7 & 140.8 \\
\hline & & Small Banks & 17.4 & 14.3 & -23.6 & 55.3 \\
\hline & & Large Banks & 22.5 & 10.6 & 7.0 & 48.0 \\
\hline & & Islamic Banks & 4.0 & 13.8 & -57.7 & 140.8 \\
\hline & \multirow{4}{*}{$\begin{array}{l}\text { Change in the log of private sector loans, sum of last four } \\
\text { quarters }\end{array}$} & All Banks & 20.4 & 36.0 & -95.7 & 280.6 \\
\hline & & Small Banks & 18.5 & 38.0 & -95.7 & 280.6 \\
\hline & & Large Banks & 3.8 & 7.7 & -10.7 & 31.1 \\
\hline & & Islamic Banks & 5.9 & 10.7 & -12.4 & 63.0 \\
\hline \multirow{4}{*}{$X_{t i-1}$} & \multirow{4}{*}{ Liquid assets to total assets } & All Banks & 16.0 & 14.8 & 3.0 & 92.2 \\
\hline & & Small Banks & 16.1 & 16.7 & 3.0 & 92.0 \\
\hline & & Large Banks & 12.3 & 3.3 & 5.8 & 25.5 \\
\hline & & Islamic Banks & 22.5 & 10.6 & 7.0 & 48.0 \\
\hline \multirow{2}{*}{$\frac{\Delta R_{t-i}}{\sum_{\Delta R}}$} & Change in three month treasury bill rate & & 0.4 & 0.7 & -0.7 & 2.5 \\
\hline & $\begin{array}{l}\text { Change in three month treasury bill rate, sum of last four } \\
\text { quarters }\end{array}$ & & 1.7 & 2.0 & -4.4 & 5.5 \\
\hline \multirow{2}{*}{$\begin{array}{l}\triangle L S M_{0} \\
\sum^{4} \triangle E S:\end{array}$} & Change in the large-scale manufacturing index & & 3.0 & 15.3 & -30.7 & 33.6 \\
\hline & $\begin{array}{l}\text { Change in the large-scale manufacturing index, sum of last } \\
\text { four quarters }\end{array}$ & & 11.9 & 15.3 & -27.6 & 40.0 \\
\hline
\end{tabular}




\section{Table 7: Loan Growth, All banks}

The dependent variable is $\Delta \log \left(L_{i t}\right)$ which is the quarterly change in the logarithm of the total amount of the loans granted to the private sector by bank $i$ in year: quarter $t$. The independent variables are: $\Delta \log \left(L_{i t-j}\right)$ which is the quarterly change in the logarithm of the total amount of the loans granted to the private sector by bank $i$ in year: quarter $t-j, \Delta R_{t-j}$ is the quarterly change in the three-month Treasury bill rate in year: quarter $t-j$,

$\llbracket\left(L S M \rrbracket_{b}(t-D)\right.$ is the quarterly change in the large scale manufacturing index in year: quarter $t$-jand $X_{i t-1}$ is the liquid assets (i.e., cash and balances with the banks) over total assets of bank $i$ in year: quarter $t$. The estimations use 756 bank - year: quarter observations. ${ }^{* * *}$ Significant at $1 \%, * *$ significant at $5 \%,{ }^{*}$ significant at $10 \%$.

(1)

(2)

Baseline

$0.34 * * *$

$-5.83 * * *$

$20.71^{*}$

$X_{t \rightarrow-1} * \sum_{j=l}^{4} \Delta R_{t-l}$

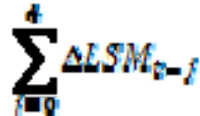

Quarter Dummies, Trend

Bank Fixed Effects

Bank Province Shares
(3)

GMM/2SLS $\quad R=$ KIBOR

$0.25^{*}$

$-5.8 * * *$

21.72

15.01

$0.36^{* * *}$

$-3.69 * * *$

19.22

(4)

With

BankProvince

Shares

(5)

With Large-scale

Manufacturing

Index

$0.40^{* * *} \quad 0.34 * * *$

$-5.95 * * * \quad-5.04 * * *$

0.19

\begin{tabular}{lllcl} 
Yes & Yes & Yes & Yes & Yes \\
Yes & Yes & Yes & No & Yes \\
No & No & No & Yes & No \\
\hline
\end{tabular}




\section{Table 8: Loan Growth, Across Bank Type}

The dependent variable is $\Delta \log \left(L_{i t}\right)$ which is the quarterly change in the logarithm of the total amount of the loans granted to the private sector by bank $i$ in year: quarter $t$. The independent variables are: $\Delta \log \left(L_{i t-j}\right)$ which is the quarterly change in the logarithm of the total amount of the loans granted to the private sector by bank $i$ in year: quarter $t-j, \Delta R_{t-j}$ is the quarterly change in the three-month Treasury bill rate in year: quarter $t-j$,

$\llbracket\left(L S M \rrbracket \_t-D\right)$ is the quarterly change in the large scale manufacturing index in year: quarter $t$-jand $X_{i t-1}$ is the liquid assets (i.e., cash and balances with the banks) over total assets of bank $i$ in year: quarter $t$. The estimations use 756 bank - year: quarter observations. $* * *$ Significant at $1 \%, * *$ significant at $5 \%, *$ significant at $10 \%$.

(2)

\begin{tabular}{|c|c|c|c|c|c|c|}
\hline $\begin{array}{l}\text { (Sum of) Estimated } \\
\text { Coefficients }\end{array}$ & Bank Type & Baseline & GMM/2SLS & $R=\mathrm{KIBOR}$ & $\begin{array}{c}\text { With } \\
\text { BankProvince } \\
\text { Shares } \\
\end{array}$ & $\begin{array}{l}\text { With Large-scale } \\
\text { Manufacturing } \\
\text { Index } \\
\end{array}$ \\
\hline \multirow{5}{*}{$\begin{array}{l}\text { Difference from Small } \\
\text { Banks }\end{array}$} & Small & $0.36 * * *$ & $0.26^{* *}$ & $0.39 * * *$ & $0.43 * * *$ & $0.46^{* * *}$ \\
\hline & Large & 0.15 & -0.03 & $0.29 * *$ & 0.15 & 0.17 \\
\hline & Islamic & 0.08 & 0.10 & 0.06 & $0.21 * * *$ & $0.25 * * *$ \\
\hline & Large & -0.21 & -0.29 & -0.10 & $-0.28 * *$ & -0.29 \\
\hline & Islamic & $-0.28 *$ & -0.15 & $-0.33 * *$ & -0.23 & $-0.21^{*}$ \\
\hline \multirow{3}{*}{$\sum_{j=1}^{4} \Delta R_{t-i}$} & Small & $-7.17 * * *$ & $-7.33 * * *$ & $-4.26 * * *$ & $-7.12 * * *$ & $-7.08 * * *$ \\
\hline & Large & $7.06^{*}$ & 7.97 & 4.99 & 4.43 & $5.75 * *$ \\
\hline & Islamic & 2.05 & $3.91 *$ & 3.85 & -2.95 & -4.25 \\
\hline \multirow{2}{*}{$\begin{array}{l}\text { Difference from Small } \\
\text { Banks }\end{array}$} & Large & $14.23 * * *$ & $15.30 * * *$ & $9.25 * *$ & $11.60 * * *$ & $12.83 * * *$ \\
\hline & Islamic & $9.22 *$ & $11.24 *$ & $8.12 * *$ & 4.17 & 2.83 \\
\hline
\end{tabular}




\begin{tabular}{|c|c|c|c|c|c|c|}
\hline & Small & $25.06 * *$ & $26.90 *$ & $18.24 *$ & $22.88^{*}$ & $27.96^{*}$ \\
\hline$X_{i b-1} * \sum \Delta R_{i-l}$ & Large & -39.20 & -41.35 & -28.83 & -17.40 & -18.23 \\
\hline & Islamic & -31.83 & -36.32 & $-27.29 *$ & -19.90 & -13.00 \\
\hline \multirow{2}{*}{$\begin{array}{l}\text { Difference from Small } \\
\text { Banks }\end{array}$} & Large & $-64.26 * *$ & $-68.25^{* *}$ & -47.08 & $-40.28 *$ & $-46.19 * *$ \\
\hline & Islamic & $-56.90 * * *$ & $-63.22 * *$ & $-45.54 * *$ & $-42.78 * *$ & $-40.97 * *$ \\
\hline \multirow{5}{*}{$\begin{array}{l}\text { Difference from Small } \\
\text { Banks }\end{array}$} & Small & & & & & 0.29 \\
\hline & Large & & & & & 0.38 \\
\hline & Islamic & & & & & $1.57 * *$ \\
\hline & Large & & & & & 0.10 \\
\hline & Islamic & & & & & $1.28 *$ \\
\hline \multirow{3}{*}{$X_{t i-1}^{*} * \sum_{i=0}^{4} \Delta E S M_{t-i}$} & Small & & & & & -1.00 \\
\hline & Large & & & & & -1.83 \\
\hline & Islamic & & & & & $-4.85^{*}$ \\
\hline \multirow{2}{*}{$\begin{array}{l}\text { Difference from Small } \\
\text { Banks }\end{array}$} & Large & & & & & -0.84 \\
\hline & Islamic & & & & & -3.85 \\
\hline Quarter Dummies, Trend & & Yes & Yes & Yes & Yes & Yes \\
\hline Bank Fixed Effects & & Yes & Yes & Yes & No & Yes \\
\hline Bank Province Shares & & No & No & No & Yes & No \\
\hline
\end{tabular}




\section{References}

Angeloni, I., A. K. Kashyap, and B. Mojon, 2003, Monetary Policy Transmission in the Euro Area, Cambridge University Press, Cambridge.

Arellano, M., and O. Bover, 1995, "Another Look at the Instrumental Variable Estimation of Error-Components Models," Journal of Econometrics 68, $29-51$.

Ashcraft, A., 2006, "New Evidence on the Lending Channel," Journal of Money, Credit and Banking 38, 751-775.

Baele, L., M. Farooq, and S. Ongena, 2010, Of Religion and Redemption: Evidence from Default on Islamic Loans, CentER - Tilburg University, Tilburg.

Beck, T., A. Demirgüç-Kunt, and O. Merrouche, 2010, Islamic vs. Conventional Banking Business Model, Efficiency and Stability, The World Bank, Washington DC.

Bernanke, B. S., 2007, The Financial Accelerator and the Credit Channel, Board of Governors of the US Federal Reserve System, Washington DC.

Bernanke, B. S., and A. S. Blinder, 1988, "Money, Credit and Aggregate Demand," American Economic Review 82, 901-921.

-, 1992, "The Federal Funds Rate and the Channels of Monetary Transmission," American Economic Review 82, 901-921.

Bernanke, B. S., M. Gertler, and S. Gilchrist, 1996, "The Financial Accelerator and the Flight to Quality," Review of Economics and Statistics 78, 1-15.

_, 1999, "The Financial Accelerator in a Quantitative Business Cycle Framework," in J. Taylor and M. Woodford, eds, Handbook of Macroeconomics, Elsevier, Amsterdam.

Bernanke, B. S., and I. Mihov, 1998, "Measuring Monetary Policy," Quarterly Journal of Economics 113, 869-902.

Black, L. K., D. Hancock, and W. Passmore, 2009, Core Deposit Funding of Subprime Mortgages and the Effect of Monetary Policy, Board of Governors of the Federal Reserve System, Washington DC.

Boschen, J. F., and L. O. Mills, 1995, "The Relation between Narrative and Money Market Indicators of Monetary Policy," Economic Inquiry 33, 24-44.

Brissimis, S. N., N. C. Kamberoglou, and G. T. Simigiannis, 2003, "Is There a BankLending Channel of Monetary Policy in Greece? Evidence from Bank-Level Data," in I. Angeloni, A. K. Kashyap, and B. Mojon, eds, Monetary Policy Transmission in the Euro Area, Cambridge University Press, Cambridge.

Cecchetti, S., 1999, "Legal Structure, Financial Structure, and the Monetary Policy Transmission Mechanism," Economic Policy Review of the Federal Reserve Bank of New York 5, 9-28.

Christiano, L. J., M. Eichenbaum, and C. Evans, 1996, "The Effects of Monetary Policy Shocks: Evidence from the Flow of Funds," Review of Economics and Statistics 78, 16-34.

Cowen, T., and R. S. Kroszner, 1990, "Mutual Fund Banking: A Market Approach," Cato Journal 10, 223-237.

de Haan, L., 2003, "The Impact of Monetary Policy on Bank Lending in the Netherlands," in I. Angeloni, A. K. Kashyap, and B. Mojon, eds, Monetary Policy Transmission in the Euro Area, Cambridge University Press, Cambridge.

Detragiache, E., P. G. Garella, and L. Guiso, 2000, "Multiple versus Single Banking Relationships: Theory and Evidence," Journal of Finance 55, 1133-1161. 
Ehrmann, M., L. Gambacorta, J. Martinez-Pagés, P. Sevestre, and A. Worms, 2001, Financial Systems and the Role of Banks in Monetary Policy Transmission in the Euro Area, European Central Bank, Frankfurt.

—, 2003, "The Effects of Monetary Policy in the Euro Area," Oxford Review of Economic Policy 19, 58-72.

Gambacorta, L., 2005, "Inside the Bank Lending Channel," European Economic Review 49, 1737-1759.

Gertler, M., and S. Gilchrist, 1993, "The Role of Credit Market Imperfections in the Monetary Transmission Mechanism: Arguments and Evidence," Scandinavian Journal of Economics 95, 43-64.

- 1994, "Monetary Policy, Business Cycles, and the Behavior of Small Manufacturing Firms," Quarterly Journal of Economics 109, 309-340.

Gertler, M., and P. Karadi, 2010, "A Model of Unconventional Monetary Policy," Journal of Monetary Economics Forthcoming.

Gertler, M., and N. Kiyotaki, 2011, "Financial Intermediation and Credit Policy in Business Cycle Analysis," in B. M. Friedman and M. Woodford, eds, Handbook of Monetary Economics, Elsevier, New York NY.

Jayaratne, J., and D. P. Morgan, 2000, "Capital Market Frictions and Deposit Constraints at Banks," Journal of Money, Credit and Banking 32, 74-92.

Judson, R. A., and A. L. Owen, 1999, "Estimating Dynamic Panel Data Models: A Guide for Macroeconomists," Economics Letters 65, 9-15.

Kashyap, A. K., and J. C. Stein, 1995, "The Impact of Monetary Policy on Bank Balance Sheets," Carnegie-Rochester Conference Series on Public Policy 42, 197202.

—, 2000, "What Do A Million Observations on Banks Say About the Transmission of Monetary Policy?," American Economic Review 90, 407-428.

Kaufmann, S., 2003, "The Cross-Sectional and the Time Dimension of the BankLending Channel: the Austrian Case," in I. Angeloni, A. K. Kashyap, and B. Mojon, eds, Monetary Policy Transmission in the Euro Area, Cambridge University Press, Cambridge.

Khan, A. K., 2010, God, Government and Outsiders: The Influence of Religious Beliefs on Depositor Behavior in an Emerging Market, Harvard, Cambridge MA.

Khan, A. K., and T. Khanna, 2010, Is Faith a Luxury for the Rich? Examining the Influence of Religious Beliefs on Individual Financial Choices, Harvard Business School, Cambridge MA.

Khwaja, A. I., and A. Mian, 2005, "Do Lenders Favor Politically Connected Firms? Rent Provision in an Emerging Financial Market," Quarterly Journal of Economics $120,1371-1411$.

—, 2008, "Tracing the Impact of Bank Liquidity Shocks: Evidence from an Emerging Market," American Economic Review 98, 1413-1442.

Kishan, R. P., and T. P. Opiela, 2000, "Bank Size, Bank Capital, and the Bank Lending Channel," Journal of Money, Credit and Banking 32.

Kiyotaki, N., and J. Moore, 2008, Liquidity, Business Cycles and Monetary Policy, Princeton University, Princeton NJ.

Lang, W. W., and L. I. Nakamura, 1995, "'Flight to Quality' in Banking and Economic Activity," Journal of Monetary Economics 36, 145-164.

Loupias, C., F. Savignac, and P. Sevestre, 2003, "Is There a Bank lending Channel in France? Evidence From Bank Panel Data," in I. Angeloni, A. K. Kashyap, and B. Mojon, eds, Monetary Policy Transmission in the Euro Area, Cambridge University Press, Cambridge. 
Mian, A., 2006, "Distance Constraints: The Limits of Foreign Lending in Poor Economies," Journal of Finance 61, 1005-1056.

Oliner, S., and G. Rudebusch, 1996, "Monetary Policy and Credit Conditions: Evidence from the Composition of External Finance: Comment," American Economic Review 86, 300-309.

Romer, C. D., and D. H. Romer, 1989, "Does Monetary Policy Matter? A New Test in the Spirit of Friedman and Schwartz," in O. J. Blanchard and S. Fischer, eds, Macroeconomics Annual, National Bureau of Economic Research, Cambridge MA.

-, 1990, "New Evidence on the Monetary Transmission Mechanism," Brookings Papers on Economic Activity 1, 149-213.

Verbeek, M., 2008, A Guide to Modern Econometrics, John Wiley \& Sons, Hoboken NJ.

Worms, A., 2003, "The Reaction of Bank Lending to Monetary Policy Measures in Germany " in I. Angeloni, A. K. Kashyap, and B. Mojon, eds, Monetary Policy Transmission in the Euro Area, Cambridge University Press, Cambridge.

Zia, B. H., 2008, "Export Incentives, Financial Constraints, and the (Mis)allocation of Credit: Micro-level Evidence from Subsidized Export Loans," Journal of Financial Economics 498-527. 